Artikel Penelitian

\title{
Mikroenkapsulasi Senyawa Fenolik Ekstrak Daun Kenikir (Cosmos caudatus K.)
}

Microencapsulation Of Phenolic Compounds From Cosmos caudatus K. Leaves Extract

Tagor Marsillam Siregar*, Clarine Kristanti

Laboratorium Kimia, Program Studi Teknologi Pangan, Fakultas Sains dan Teknologi, Universitas Pelita Harapan, Jakarta

*Korespondensi dengan penulis (tagor.siregar@uph.edu)

Artikel ini dikirim pada tanggal 27 September 2018 dan dinyatakan diterima tanggal 25 Februari 2019. Artikel ini juga dipublikasi secara online melalui https://ejournal2.undip.ac.id/index.php/jatp. Hak cipta dilindungi undang-undang. Dilarang diperbanyak untuk tujuan komersial.

Diproduksi oleh Indonesian Food Technologists ${ }^{\circledR}$ (C2019

\begin{abstract}
Abstrak
Daun Kenikir (Cosmos caudatus K.) memiliki kandungan senyawa fenolik dan aktivitas antioksidan tinggi yang telah diketahui sensitif terhadap cahaya, oksigen dan panas. Enkapsulasi dapat melindungi senyawa fenolik dalam ekstrak. Penelitian ini bertujuan untuk mempelajari pengaruh rasio bahan inti dan bahan penyalut (1:10 dan 1: 20) dan suhu inlet spray dryer $\left(125,150\right.$ dan $\left.175^{\circ} \mathrm{C}\right)$ terhadap karakteristik mikrokapsul. Pada penelitian tahap pendahuluan, daun kenikir diekstraksi menggunakan pelarut etanol, kemudian ekstrak yang diperoleh dianalisis aktivitas antioksidan dan total fenolik. Pada tahap selanjutnya ekstrak dienkapsulasi dan mikrokapsul yang diperoleh dianalisis powder recovery, kandungan total fenolik, effisiensi enkapsulasi, aktivitas antioksidan dan ukuran partikel. Hasil penelitian menunjukkan bahwa rasio bahan inti dan bahan penyalut dan suhu inlet spray dryer mempengaruhi powder recovery, total fenolik, effisiensi enkapsulasi, aktivitas antioksidan dan ukuran partikel mikrokapsul. Perlakuan dengan rasio bahan inti dan bahan penyalut sebesar $1: 20$ dan suhu inlet spray dryer $125^{\circ} \mathrm{C}$ menghasilkan mikrokapsul dengan powder recovery 59,87\%, total fenol 24,644 mgGAE/g sampel, efisiensi enkapsulasi 98,820\%, aktivitas antioksidan $\left(\mathrm{IC}_{50}\right) 1711,804 \mathrm{ppm}$ dan ukuran partikel 1,55 $\mu \mathrm{m}$. Kesimpulannya, rasio bahan inti dan bahan penyalut serta suhu inlet spray drying merupakan faktor yang sangat berperan penting dalam karakteristik mikroenkapsul.
\end{abstract}

Kata kunci: antioksidan, Cosmos caudatus K., mikroenkapsulasi, fenol, spray drying

\begin{abstract}
Cosmos caudatus $\mathrm{K}$. leaves are high in total phenolic content and antioxidant activity that are sensitive to light, oxygen, and heat. Encapsulation process may protect the phenolic compounds of extract. This research was aimed to study the effect of the leaves extract and coating ratio (1:10 and 1:20) and various spray drying inlet temperatures $\left(125,150\right.$, and $\left.175^{\circ} \mathrm{C}\right)$ towards the characteristics of microcapsules. In preliminary stage, Cosmos caudatus $\mathrm{K}$. leaves were extracted with ethanol. The extract was analyzed for antioxidant activity and total phenolic content. In the beginning stage, the extract were encapsulated. The microcapsules were analyzed for powder recovery, total phenolic content, encapsulation efficiency, antioxidant activity, and particle size. As results, the extract and coating ratio as well as inlet temperature affected the powder recovery, total phenolic content, encapsulation efficiency, antioxidant activity, and particle size of microcapsules. Microcapsules with ratio of 1:20 and inlet temperature of $125^{\circ} \mathrm{C}$ provided the best result with powder recovery $59.87 \%$, total phenolic content $24.644 \mathrm{mg} \mathrm{GAE} / \mathrm{g} \mathrm{sample,}$ encapsulation efficiency $98.820 \%, I C_{50} 1711.804$ ppm, and particle size $1.55 \mu \mathrm{m}$. As conclusion, the extract leaves and coating ratio as well as inlet temperature effected the characteristic of microencapsules.
\end{abstract}

Keywords: antioxidant, Cosmos caudatus K., microencapsulation, phenolic compounds, spray drying

\section{Pendahuluan}

Kenikir (Cosmos caudatus K.) merupakan tanaman yang dapat ditemukan di wilayah Amerika Tengah dan Asia Tenggara (Cheng et al., 2015). Daun kenikir memiliki berbagai manfaat, seperti antihipertensi, antidiabetes,dan antiinflamasi, serta meningkatkan sirkulasi darah, memperkuat struktur tulang, dan mengobati luka (Amna et al., 2013; Chan et al., 2016; Rahman et al., 2017). Daun kenikir memiliki kandungan senyawa fenolik dan aktivitas antioksidan yang tinggi. Ekstrak etanol dari daun kenikir memiliki aktivitas antioksidan dengan nilai $\mathrm{IC}_{50} 72 \mu \mathrm{g} / \mathrm{ml}$ dan kandungan senyawa fenolik sebesar $377,1 \mathrm{mg}$ GAE/g sampel (Mediani et al., 2013; Rahman et al., 2016).

Mikroenkapsulasi adalah proses penyalutan bahan inti (core) yang berwujud partikel padat, cairan, atau gas dengan menggunakan bahan penyalut (coating). Proses ini bertujuan untuk melindungi bahan inti berupa senyawa bioaktif seperti senyawa fenolik dari berbagai pengaruh lingkungan seperti cahaya, oksigen, air, dan suhu (Sobel et al., 2014). Metode yang paling umum digunakan dalam mikroenkapsulasi senyawa fenolik adalah spray drying karena prosesnya yang sederhana dan relatif murah. Dalam proses mikroenkapsulasi, rasio bahan inti dan bahan penyalut serta suhu inlet pada spray drying dapat mempengaruhi karakteristik dari mikrokapsul yang dihasilkan (Cilek et al., 2012; Mishra et al., 2014). Menurut Cilek et al, 2012, Mikrokapsul dengan rasio bahan inti dan bahan penyalut 1 : 20 memiliki efisiensi enkapsulasi yang lebih tinggi $(92,26 \%)$ dan ukuran partikel yang lebih kecil 
dibandingkan dengan mikrokapsul dengan dengan rasio $1: 10$ (efisiensi enkapsulasi 77,83\%).

Tujuan dari penelitian ini adalah mengetahui pengaruh rasio bahan inti dan bahan penyalut serta suhu inlet spray drying terhadap powder recovery, kandungan total fenolik, efisiensi enkapsulasi, aktivitas antioksidan, dan ukuran partikel mikrokapsul ekstrak daun kenikir.

\section{Materi dan Metode \\ Materi}

Bahan yang digunakan dalam penelitian ini adalah daun kenikir (Cosmos caudatus K.) yang diperoleh dari Pasar Kelapa Dua, Tangerang, Banten, whey protein isolate, dan maltodekstrin. Alat yang digunakan adalah cabinet dryer (lokal), Büchi rotary evaporator (R-210, Switzerland), timbangan analitik (Mettler Toledo, USA), ultrasonikator (Krisbow, China), Büchi mini spray dryer (B-290, Switzerland), spektrofotometer visible (Genesys 20, USA), dan mikroskop (Olympus CX3, USA).

\section{Ekstraksi Daun Kenikir}

Proses ekstraksi daun kenikir menggunakan pelarut etanol, dilakukan berdasarkan metode Noriham et al. (2015) yang dimodifikasi. Sebelum dilakukan proses ekstraksi, daun kenikir dicuci dengan air lalu dikeringkan dalam cabinet dryer pada suhu $40^{\circ} \mathrm{C}$ hingga kadar air di bawah 10\%. Setelah itu, daun kering dihaluskan dengan dry blender dan diayak dengan ayakan 35 mesh. Ekstraksi dilakukan dengan metode maserasi selama 24 jam pada suhu ruang dengan perbandingan serbuk daun dan etanol yaitu 1:10.

\section{Mikroenkapsulasi Ekstrak Daun Kenikir}

Mikroenkapsulasi dilakukan dengan metode spray drying. Bahan inti, yaitu ekstrak etanol daun kenikir dan bahan penyalut, yaitu maltodekstrin dan whey protein isolate dengan rasio $1: 1$, dicampurkan sehingga menghasilkan larutan dengan rasio bahan inti dan bahan penyalut adalah 1:10 dan 1:20 (0,4 g dan 0,2 g massa kering bahan inti dengan $4 \mathrm{~g}$ massa kering bahan penyalut) lalu dilarutkan dengan air hingga $500 \mathrm{ml}$. Setelah itu, dilakukan ultrasonikasi dengan frekuensi 47 $\mathrm{kHz}$ selama 90 menit dan spray drying dengan suhu inlet 125,150 , dan $175^{\circ} \mathrm{C}$, aspirator $100 \%$, pump $35 \%$, dan flow rate $40 \mathrm{~mm}$ (Paini et al., 2015).

\section{Kadar Air dan Powder Recovery}

Analisis kadar air dilakukan dengan menggunakan metode oven (AOAC, 2005). Penentuan Powder recovery (PR) dilakukan sesuai dengan LeonMartinez et al. (2010) dan ditentukan dengan membandingkan massa bubuk yang didapatkan setelah spray drying dengan massa padatan sebelum spray drying.

\section{Kandungan Total Fenolik}

Kandungan senyawa fenolik ditentukan menggunakan pereaksi Folin-Ciocalteau dan dilakukan menurut Anesini et al. (2008). Ekstrak dilarutkan dalam etanol, kemudian larutan sebanyak $0,3 \mathrm{ml}$ ditambahkan dengan $1,5 \mathrm{ml}$ pereaksi Folin-Ciocalteau 10\% dan 1,2 ml larutan natrium karbonat $\left(\mathrm{Na}_{2} \mathrm{CO}_{3}\right)$ 7,5\%. Larutan kemudian divortex dan diinkubasi selama 1 jam pada suhu ruang. Setelah itu, absorbansi larutan diukur menggunakan spektrofotometer pada panjang gelombang $765 \mathrm{~nm}$. Prosedur diulangi untuk menganalisis kandungan total fenolik dari larutan feed dan mikrokapsul, namun larutan feed dan mikrokapsul dilarutkan dalam air. Larutan asam galat digunakan sebagai standar dan hasil analisis kandungan total fenolik dinyatakan dalam mg GAE/g sampel.

\section{Efisiensi Enkapsulasi}

Efisiensi enkapsulasi merupakan perbandingan antara kandungan total fenolik yang terenkapsulasi dengan kandungan total fenolik dari larutan sebelum enkapsulasi. Penentuan effisiensi enkapsulasi (\%) dilakukan sesuai dengan Isailovic et al. (2012).

\section{Aktivitas Antioksidan}

Aktivitas antioksidan ditentukan menggunakan pereaksi DPPH dan dilakukan sesuai dengan Amin dan Lee, (2005). Ekstrak dilarutkan dengan etanol dan larutan ekstrak sebanyak $0,5 \mathrm{ml}$ ditambahkan dengan $1,5 \mathrm{ml}$ larutan etanol DPPH 0,2 mM kemudian larutan divortex dan disimpan dalam kondisi gelap selama 30 menit pada suhu ruang. Setelah itu, absorbansi larutan diukur menggunakan spektrofotometer pada panjang gelombang $517 \mathrm{~nm}$ dengan etanol sebagai blanko. Etanol dan larutan DPPH digunakan sebagai kontrol. Prosedur tersebut diulangi untuk analisis aktivitas antioksidan larutan mula-mula dan mikrokapsul, namun pelarut yang digunakan adalah air. Persen inhibisi dapat dihitung dengan perhitungan absorbansi kontrol dikurangi absorbansi sampel lalu dibagi absorbansi kontrol dikalikan $100 \%$. Nilai $I_{50}$ sampel diperoleh dari persamaan regresi linear $y=0,5573 x+6,1244$, dengan $R^{2}=0,9971$.

\section{Ukuran Partikel}

Penentuan ukuran partikel dilakukan menurut Frascareli et al. (2011) dengan modifikasi. Ukuran partikel dari mikrokapsul ditentukan dengan cara mengamati mikrokapsul di bawah mikroskop dengan perbesaran 1000 kali. Diameter partikel diukur dengan menggunakan software Olympus Stream Start.

\section{Analisis Data}

Rancangan percobaan pada penelitian ini adalah Rancangan Acak Lengkap dengan dua faktor, yaitu rasio bahan inti dan bahan penyalut sebesar 1:10 dan 1:20 serta suhu inlet spray drying, yaitu 125,150 , dan $175^{\circ} \mathrm{C}$. Percobaan dilakukan dengan tiga kali pengulangan. Data dianalisis secara statistik dengan ANOVA menggunakan software SPSS versi 22.

\section{Hasil dan Pembahasan}

Karakteristik Ekstrak Etanol Daun Kenikir dan Bahan Penyalut

Hasil analisis pada Tabel 1 menunjukkan bahwa rendemen dari ekstrak daun kenikir adalah $5,33 \%$. Hasil penelitian Javadi et al. (2014) menunjukkan bahwa 
rendemen dari ekstrak etanol daun kenikir adalah $21,0 \%$. Rendemen ekstrak yang lebih tinggi tersebut disebabkan oleh ekstraksi yang dilakukan dengan metode sonikasi (Moshawih et al., 2017). Kandungan senyawa fenolik ekstrak daun kenikir adalah 312,075 mg GAE/g sampel. Berdasarkan hasil penelitian Rahman et al. (2016), kandungan fenolik total pada ekstrak etanol daun kenikir adalah $377,1 \mathrm{mg}$ GAE/g sampel. Kandungan senyawa fenolik yang lebih tinggi pada penelitian Rahman et al. (2016) dapat disebabkan oleh metode pengeringan yang dilakukan dengan freeze dryer, sedangkan dalam penelitian ini daun kenikir dikeringkan menggunakan cabinet dryer dengan suhu $40^{\circ} \mathrm{C}$. Senyawa fenolik merupakan senyawa yang sensitif terhadap panas sehingga pengeringan dengan suhu yang lebih tinggi dapat menyebabkan penurunan kandungan senyawa fenolik (Sari et al., 2012). Ekstrak daun kenikir dapat dikategorikan sebagai ekstrak dengan kandungan senyawa fenolik yang tinggi (>50 mg GAE/g sampel) (Rufino et al., 2010).

Tabel 1. Karakteristik ekstrak daun kenikir

\begin{tabular}{ll}
\hline Parameter & \multicolumn{1}{c}{ Kadar } \\
\hline Kadar air $(\%)$ & $6,1840 \pm 0,1117$ \\
Rendemen (\%) & $5,33 \pm 0,25$ \\
Total fenolik & $312,075 \pm 4,772$ \\
(mg GAE/g sampel) & $74,556 \pm 3,466$ \\
\hline
\end{tabular}

Tabel 2 Karakteristik Bahan Penyalut

\begin{tabular}{lccc}
\hline Bahan penyalut & $\begin{array}{c}\text { Kadar air } \\
(\%)\end{array}$ & $\begin{array}{c}\text { Total fenolik } \\
(\mathrm{mg} \mathrm{GAE} / \mathrm{g} \\
\text { sampel) }\end{array}$ & $\begin{array}{c}\mathrm{IC}_{50} \\
(\mathrm{ppm})\end{array}$ \\
\hline $\begin{array}{lccc}\text { Maltodekstrin } \\
\begin{array}{l}\text { Whey Protein } \\
\text { Isolate }\end{array}\end{array}$ & $7,4246 \pm 0,0292$ & - & $>5000$ \\
\hline
\end{tabular}

Hasil analisis menunjukkan bahwa ekstrak daun kenikir memiliki aktivitas antioksidan dengan nilai $\mathrm{IC}_{50}$ sebesar 74,556 ppm. Hasil penelitian Mediani et al. (2013) menunjukkan bahwa ekstrak etanol daun kenikir memiliki aktivitas antioksidan dengan nilai $\mathrm{IC}_{50} 72 \mu \mathrm{g} / \mathrm{ml}$. Berdasarkan klasifikasi aktivitas antioksidan menurut Jun et al. (2003), ekstrak daun kenikir dapat dikategorikan sebagai ekstrak yang aktif yang mempunyai $\mathrm{IC}_{50}$ berkisar $50-100 \mu \mathrm{g} / \mathrm{ml}$. Hasil analisis pada Tabel 2 menunjukkan bahwa bahan penyalut tidak memberikan kontribusi terhadap kandungan senyawa fenolik dan aktivitas antioksidan pada larutan feed atau larutan mula-mula.

\section{Kadar Air Mikrokapsul Ekstrak Daun Kenikir}

Figur 1 menunjukkan bahwa mikrokapsul dengan rasio bahan inti dan bahan penyalut pada rasio 1:10 memiliki kadar air yang lebih tinggi dibandingkan dengan mikrokapsul dengan rasio 1:20 pada suhu inlet yang sama. Hal ini sesuai dengan hasil penelitian Saikia et al. (2015) yang menunjukkan bahwa mikrokapsul dengan rasio bahan inti dan bahan penyalut pada 1:10 memiliki kadar air yang lebih tinggi dibandingkan dengan mikrokapsul dengan rasio 1:20. Hasil penelitian Ho et al., (2015) juga menunjukkan bahwa penurunan rasio bahan inti dan bahan penyalut dari 1:1 ke 1:4 menyebabkan penurunan kadar air bubuk. Hal ini dapat disebabkan oleh viskositas larutan feed, dimana larutan feed dengan rasio bahan inti dan bahan penyalut sebesar 1:10 mengandung 0,4 g ekstrak dan larutan feed dengan rasio 1:20 mengandung 0,2 g ekstrak sehingga larutan feed dengan rasio 1:10 memiliki viskositas yang lebih tinggi. Menurut Ho et al. (2015), viskositas larutan feed yang lebih tinggi dapat menyebabkan ukuran droplet semakin besar sehingga difusi air dari dalam ke lapisan luar droplet terhambat dan kadar air bubuk meningkat.

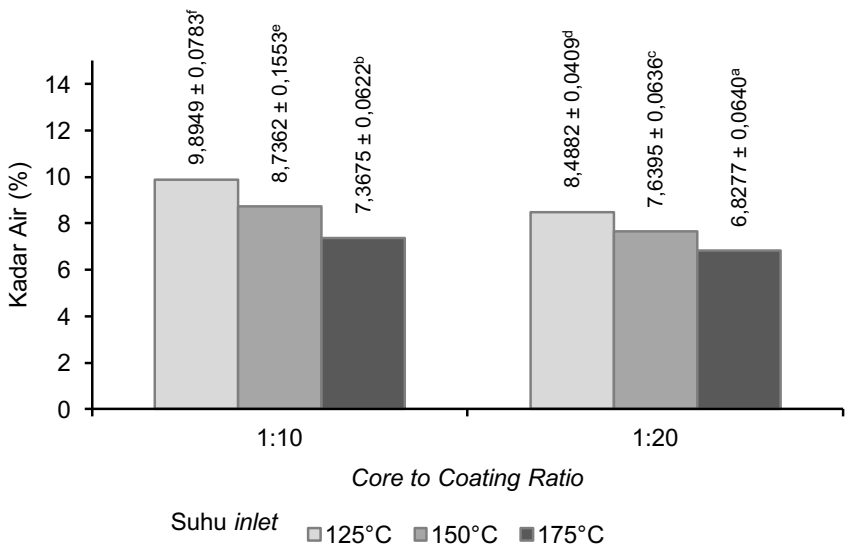

Figur 1. Kadar air mikrokapsul

Keterangan: Notasi huruf yang berbeda menunjukkan adanya perbedaan nyata $(p \leq 0,05)$

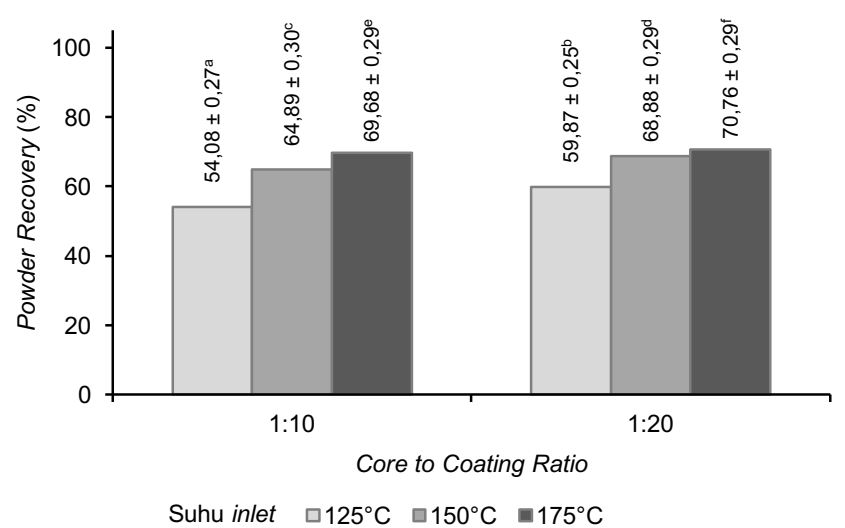

Figur 2. Powder recovery mikrokapsul Keterangan: Notasi huruf yang berbeda menunjukkan adanya perbedaan nyata $(p \leq 0,05)$

\section{Powder Recovery}

Berdasarkan Figur 2, mikrokapsul dengan rasio bahan inti:bahan penyalut 1:10 memiliki powder recovery yang lebih rendah dibandingkan mikrokapsul dengan rasio bahan inti dan bahan penyalut 1:20 pada suhu inlet yang sama. Hasil penelitian Ho et al. (2015) menunjukkan bahwa penurunan rasio bahan inti:bahan penyalut menyebabkan powder recovery dari mikrokapsul meningkat. Menurut Quek et al. (2007), peningkatan jumlah bahan penyalut dapat menyebabkan peningkatan powder recovery mikrokapsul yang dihasilkan. Hal ini berkaitan dengan kadar air, dimana mikrokapsul dengan rasio bahan inti dan bahan penyalut 1:10 memiliki kadar air yang lebih tinggi dibandingkan mikrokapsul dengan rasio bahan inti dan bahan penyalut 
1:20. Semakin kering bubuk hasil spray dry, maka semakin sedikit bubuk yang menempel pada dinding drying chamber dan semakin banyak bubuk yang terkumpul sehingga powder recovery dapat meningkat (Quek et al., 2007).

Hasil analisis pada Figur 2 menunjukkan bahwa semakin tinggi suhu inlet spray drying, maka powder recovery mikrokapsul yang dihasilkan dapat semakin tinggi. Hasil penelitian Jatupornwipat et al.(2017) dan Ho et al. (2015) juga menunjukkan kenaikkan suhu inlet dapat meningkatkan powder recovery. Menurut Quek et al. (2007), semakin kering bubuk hasil spray dry, maka bubuk yang akan menempel pada dinding drying chamber semakin sedikit sehingga bubuk yang terkumpul akan semakin banyak dan powder recovery bubuk dapat meningkat.

\section{Kandungan Total Fenolik}

Mikrokapsul dengan rasio bahan inti dan bahan penyalut sebesar 1:10 memiliki kandungan total fenolik yang lebih tinggi dibandingkan dengan mikrokapsul dengan rasio bahan inti dan bahan penyalut 1:20 seperti yang dapat dilihat pada Figur 3 . Hal ini disebabkan oleh perbedaan jumlah bahan inti (ekstrak daun kenikir) yang digunakan dalam pembuatan larutan feed dengan rasio bahan inti dan bahan penyalut 1:10 dan 1:20, yaitu masing-masing sebesar $0,4 \mathrm{~g}$ dan $0,2 \mathrm{~g}$.

Hasil analisis menunjukkan bahwa suhu inlet spray drying mempengaruhi kandungan total fenolik mikrokapsul, seperti yang dapat dilihat pada Figur 4. Mikrokapsul dengan suhu inlet $125^{\circ} \mathrm{C}$ memiliki kandungan total fenolik yang lebih tinggi dibandingkan mikrokapsul dengan suhu inlet $150^{\circ} \mathrm{C}$. El-Hamzy dan ElKholany (2014) menyatakan bahwa kenaikkan suhu inlet spray drying dari $120^{\circ} \mathrm{C}$ ke $160^{\circ} \mathrm{C}$ menyebabkan penurunan kandungan total fenolik, dimana mikrokapsul dengan perlakuan suhu inlet spray drying $175^{\circ} \mathrm{C}$ memiliki kandungan total fenolik yang lebih tinggi dibandingkan mikrokapsul dengan perlakuan suhu inlet $150^{\circ} \mathrm{C}$. Hasil penelitian yang telah dilakukan oleh El-Hamzy dan ElKholany (2014) menunjukkan bahwa kandungan total fenolik mikrokapsul meningkat pada suhu inlet diatas $160^{\circ} \mathrm{C}$

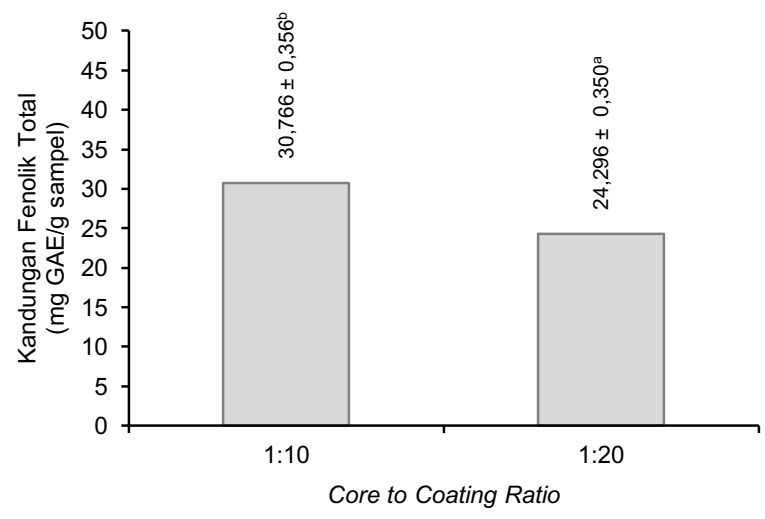

Figur 3. Pengaruh rasio bahan inti:bahan penyalut terhadap kandungan total fenolik mikrokapsul

Keterangan: Notasi huruf yang berbeda menunjukkan adanya perbedaan nyata $(p \leq 0,05)$
Efisiensi Enkapsulasi

Mikrokapsul dengan rasio bahan inti:bahan penyalut 1:20 memiliki efisiensi enkapsulasi yang lebih tinggi dibandingkan dengan mikrokapsul dengan rasio bahan inti:bahan penyalut 1:10 seperti yang dapat dilihat pada Figur 5. Hasil penelitian Akdeniz et al. (2017) dan Cilek et al. (2012) menunjukkan efisiensi enkapsulasi mikrokapsul dengan rasio 1:20 dapat lebih tinggi dibandingkan dengan rasio 1:10. Hasil penelitian Ho et al. (2015) menunjukkan bahwa penurunan rasio bahan inti dan bahan penyalut dapat meningkatkan efisiensi enkapsulasi senyawa fenolik karena terbentuknya dinding dari bahan penyalut selama proses spray drying sehingga semakin banyak bahan penyalut, maka dinding yang dapat melindungi bahan inti dapat terbentuk dengan lebih baik.

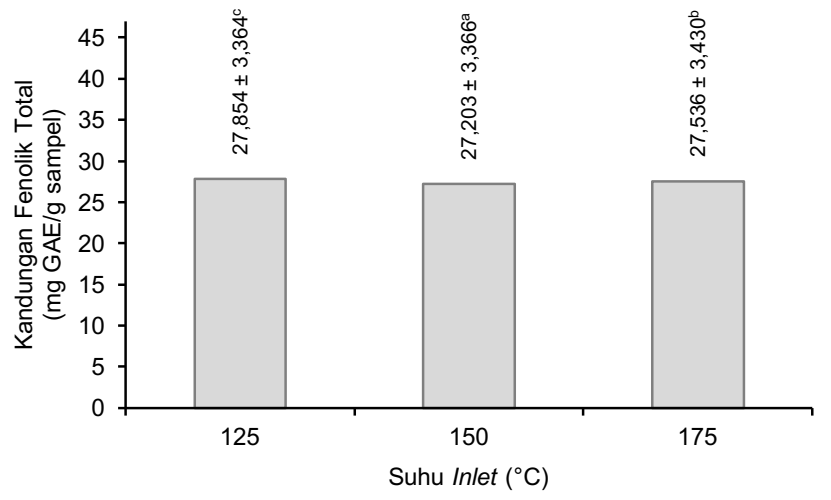

Figur 4. Pengaruh suhu inlet spray drying terhadap kandungan total fenolik mikrokapsul

Keterangan: Notasi huruf yang berbeda menunjukkan adanya perbedaan nyata $(p \leq 0,05)$

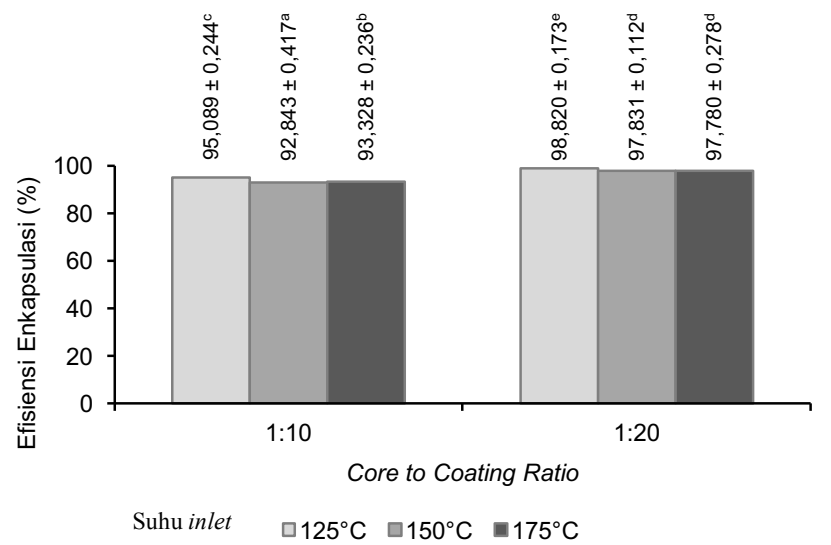

Figur 5. Efisisensi enkapsulasi mikrokapsul Keterangan: Notasi huruf yang berbeda menunjukkan adanya perbedaan nyata $(p \leq 0,05)$

Mikrokapsul dengan perlakuan suhu inlet spray drying $125^{\circ} \mathrm{C}$ memiliki efisiensi enkapsulasi yang lebih tinggi dibandingkan mikrokapsul dengan perlakuan suhu inlet $150^{\circ} \mathrm{C}$ seperti yang dapat dilihat pada Figur 5 . Hal ini menunjukkan kandungan total fenolik mikrokapsul dengan perlakuan suhu inlet $125^{\circ} \mathrm{C}$ lebih tinggi dibandingkan kandungan total fenolik mikrokapsul dengan perlakuan suhu inlet $150^{\circ} \mathrm{C}$. Hasil penelitian ElHamzy dan El-Kholany (2014) menunjukkan kenaikkan 
suhu inlet dari $120^{\circ} \mathrm{C}$ ke $160^{\circ} \mathrm{C}$ akan menyebabkan kandungan total fenolik mikrokapsul menurun.

Mikrokapsul dengan suhu inlet $175^{\circ} \mathrm{C}$ memiliki efisiensi enkapsulasi yang lebih tinggi dibandingkan dengan mikrokapsul dengan suhu inlet $150^{\circ} \mathrm{C}$ pada rasio 1:10 (Figur 5), sedangkan pada rasio 1:20, tidak terdapat perbedaan efisiensi enkapsulasi yang signifikan diantara mikrokapsul dengan perlakuan suhu inlet 150 dan $175^{\circ} \mathrm{C}$. Hal ini berkaitan dengan kenaikkan kandungan total fenolik mikrokapsul pada suhu di atas $160^{\circ} \mathrm{C}$, yang dapat disebabkan oleh proses polimerisasi serta sintesis polifenol (El-Hamzy dan El-Kholany, 2014).

\section{Aktivitas Antioksidan}

Figur 6 menunjukkan mikrokapsul dengan rasio bahan inti dan bahan penyalut sebesar 1:10 memiliki aktivitas antioksidan yang lebih tinggi dibandingkan dengan mikrokapsul dengan rasio 1:20. Hal ini disebabkan oleh perbedaan jumlah ekstrak daun kenikir yang terdapat dalam larutan feed.

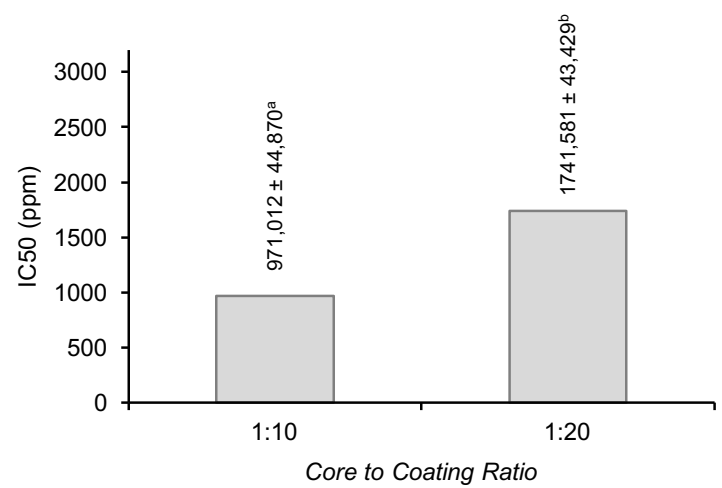

Figur 6. Pengaruh rasio bahan inti:bahan penyalut terhadap aktivitas antioksidan mikrokapsul

Keterangan: Notasi huruf yang berbeda menunjukkan adanya perbedaan nyata $(p \leq 0,05)$

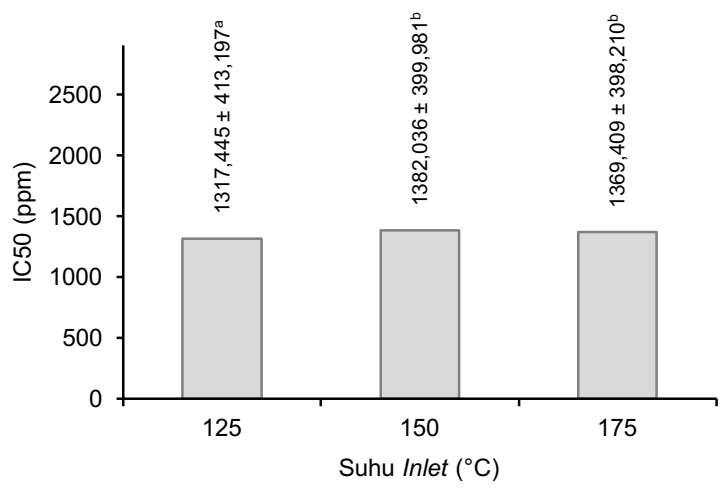

Figur 7. Pengaruh suhu inlet spray drying terhadap aktivitas antioksidan mikrokapsul

Keterangan: Notasi huruf yang berbeda menunjukkan adanya perbedaan nyata $(p \leq 0,05)$

Pengaruh suhu inlet terhadap aktivitas antioksidan mikrokapsul dapat dilihat pada Figur 7 . Mikrokapsul dengan perlakuan suhu inlet $125^{\circ} \mathrm{C}$ memiliki nilai $\quad I_{50}$ yang secara signifikan lebih rendah dibandingkan mikrokapsul dengan perlakuan suhu inlet spray drying 150 dan $175^{\circ} \mathrm{C}(\mathrm{p} \leq 0,05)$. Hasil penelitian Jatupornwipat et al. (2017), El-Hamzy dan El-Kholany (2014) dan Mishra et al. (2014) menunjukkan kenaikkan suhu inlet spray drying dapat menurunkan aktivitas antioksidan mikrokapsul sebagai akibat perlakuan suhu tinggi selama proses spray drying yang menyebabkan terjadinya penurunan aktivitas antioksidan.

Korelasi antara Kandungan Total Fenolik dengan Aktivitas Antioksidan

Hanalisis statistik menunjukkan bahwa terdapat korelasi antara kandungan total fenolik dengan aktivitas antioksidan mikrokapsul dengan nilai $\mathrm{R}^{2}$ sebesar 0,9956 yang didapatkan dari persamaan regresi $y=-$ $118,9 x+4629,7$. Semakin tinggi kandungan total fenolik mikrokapsul, maka aktivitas antioksidan dari mikrokapsul semakin tinggi. Hal ini sesuai dengan Sulaiman dan Balachandran (2012), yang menyatakan bahwa senyawa fenolik berkontribusi terhadap aktivitas antioksidan. Hasil penelitian El-Hamzy dan El-Kholany (2014), Mishra et al. (2014), dan Jatupornwipat et al. (2017) menunjukkan bahwa mikrokapsul dengan kandungan total fenolik yang lebih tinggi memiliki aktivitas antioksidan yang lebih tinggi.

\section{Ukuran Partikel}

Mikrokapsul dengan rasio bahan inti dan bahan penyalut sebesar 1:10 memiliki ukuran partikel yang lebih besar dibandingkan mikrokapsul dengan rasio 1:20 seperti yang dapat dilihat pada Figur 8. Akdeniz et al. (2017) dan Cilek et al. (2012) menyatakan bahwa mikrokapsul dengan rasio bahan inti dan bahan penyalut 1:20 memiliki ukuran partikel yang lebih kecil dibandingkan dengan mikrokapsul dengan rasio 1:10. Hasil penelitian Ho et al. (2015) menunjukkan penurunan rasio menyebabkan mikrokapsul memiliki ukuran partikel yang lebih kecil. Ukuran partikel mikrokapsul berkaitan dengan kadar air, dimana kadar air yang lebih tinggi dapat menyebabkan terjadinya aglomerasi partikel sehingga dihasilkan mikrokapsul dengan ukuran partikel yang lebih besar.

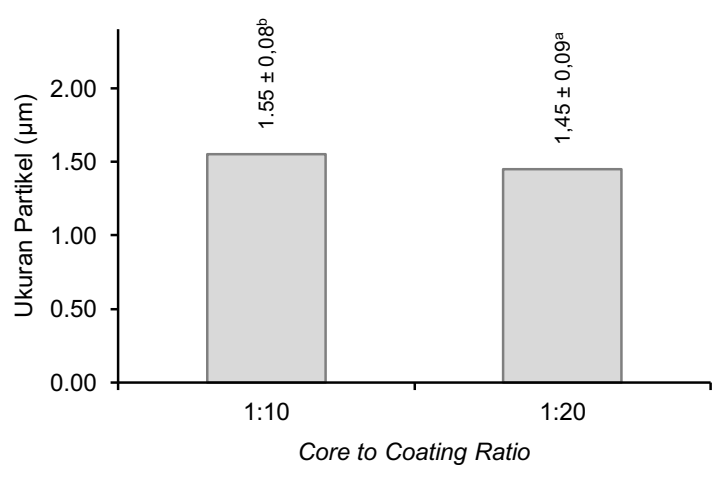

Figur 8. Pengaruh rasio bahan inti:bahan penyalut terhadap ukuran partikel

Keterangan: Notasi huruf yang berbeda menunjukkan adanya perbedaan nyata $(p \leq 0,05)$

Figur 9 menunjukkan kenaikkan suhu inlet spray drying menyebabkan ukuran partikel mikrokapsul yang 
dihasilkan semakin kecil. Hasil penelitian El-Hamzy dan El-Kholany (2014) dan Mishra et al. (2014) juga menunjukkan kenaikkan suhu inlet menyebabkan bubuk mikrokapsul yang dihasilkan memiliki ukuran partikel yang lebih kecil. Jatupornwipat et al. (2017) dan Samborska et al. (2005) menyatakan bahwa kenaikkan suhu inlet spray drying dapat menyebabkan penurunan kadar air bubuk mikrokapsul. Menurut Ho et al. (2015), ukuran partikel yang lebih besar dapat disebabkan oleh kadar air mikrokapsul yang lebih tinggi akibat terjadinya aglomerasi partikel.

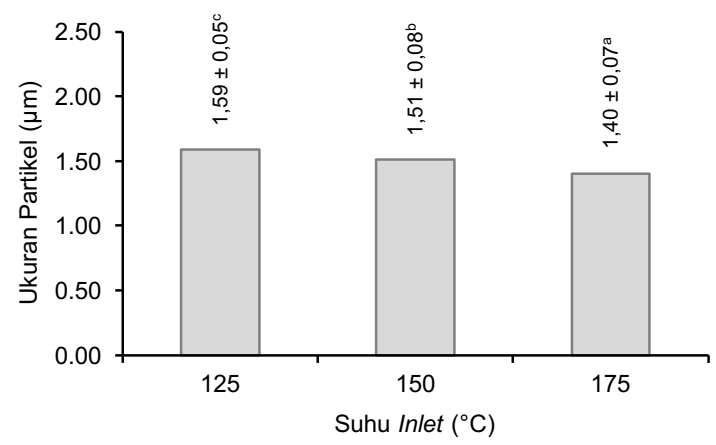

Figur 9. Pengaruh suhu inlet spray drying terhadap ukuran partikel

Keterangan: Notasi huruf yang berbeda menunjukkan adanya perbedaan nyata $(p \leq 0,05)$

\section{Kesimpulan}

Rasio bahan inti dan bahan penyalut serta suhu inlet spray drying mempengaruhi powder recovery, kandungan fenolik total, efisiensi enkapsulasi, aktivitas antioksidan, dan ukuran partikel mikrokapsul yang dihasilkan. Karakteristik mikrokapsul ekstrak daun kenikir yang terbaik berdasarkan hasil penelitian adalah mikrokapsul dengan rasio bahan inti dan bahan penyalut sebesar 1:20 dan suhu inlet spray drying sebesar $125^{\circ} \mathrm{C}$.

\section{Daftar Pustaka}

Akdeniz, B., Sumnu, G., Sahin, S. 2017. The effects of maltodextrin and gum arabic on encapsulation of onion skin phenolic compounds. Chemical Engineering Transaction 57(1): 1891-1896. DOI: 10.3303/CET1757316.

Amin, I. dan Lee, W. Y. 2005. Effect of different blanching times on antioxidant properties in selected cruciferous vegetables. Journal of the Science and Food Agriculture 85(13): 2314-2320.DOI: 10.1002/jsfa.2261

Amna, O. F., Nooraain, H., Noriham, A., Azizah, A. H., dan Husna R. N. 2013. Acute and oral subacute toxicity study of ethanolic extract of Cosmos caudatus leaf in sprague dawley rats. Int. Journal of Bioscience Biochemistry and Bioinformatics 3(4): 301-305.

Anesini, C., Ferraro, G. E., dan Filip, R. 2008. Total polyphenol content and antioxidant capacity of commercially available tea (Camellia sinensis) in Argentina. Journal of Agricultural and Food Chemistry 56(19): 9225-9229.DOI: 10.1021/ jf8022782
AOAC. 2005. "Official Methods of Analysis." Association of Official Analytical Chemists International, Washington.

Chan, E. W. C., Wong, S. K., dan Chan, H. T. 2016. Ulam herbs of Oenanthe javanica and Cosmos caudatus: An overview on their medicinal properties. Journal of Natural Remedies 16(4): 137-147.DOI:10.18311/jnr/2016/8370

Cheng, S. H., Barakatun-Nisak, M. Y., Anthony, J., dan Ismail, A. 2015. Potential medicinal benefits of Cosmos caudatus (ulam raja): A scoping review. Journal of Research in Medical Sciences 20(10): 1000-1006.DOI:10.4103/1735-1995.172796

Cilek, B., Luca, A., Hasirci, V., Sahin, S., dan Sumnu, G. 2012. Microencapsulation of phenolic compounds extracted from sour cherry pomace: Effect of formulation, ultrasonication time and core to coating ratio. European Food Research and Technology 235: 587-596. DOI:10.1007/s00217012-1786-8

El-Hamzy, E. M. A. dan El-Kholany, E. A. 2014. Effects of spray drying conditions on the physicochemical and antioxidant properties of the licorice (Glycyrrhizaglabra) powder and evaluation of their antimicrobial activity. Journal of Applied Sciences Research 10(13): 72-86.

Frascareli, E. C., Silva, V. M., Tonon, R. V., dan Hubinger, M. 2011. Physicochemical properties of coffee oil microcapsules produced by spray drying. III Jornadas Internacionais.

Ho, L. P., Pham, A. H., dan Le, V. V. M. 2015. Effects of core/wall ratio and inlet temperature on the retention of antioxidant compounds during the spray drying of sim (Rhodomyrtus tomentosa) juice. Journal of Food Processing and Preservation 39(6): 2088-2095. DOI: 10.1111/ jfpp. 12452

Isailovic, B., Kalusevic, A., Zurzul, N., Coelho, M. T., Dordevic, V., Alves, V. D., Sousa, I., MoldaoMartins, M., Bugarski, B., dan Nedovic, V. A. 2012. Microencapsulation of natural antioxidants from Pterospartum tridentatum in different alginate and inulin systems. Central European Congress on Food 6: 1075-1081.

Jatupornwipat, K., Limwikrant, W., Anantachoke, N., dan Lomarat, P. 2017. Effect of spray drying condition on physical and antioxidant properties of acerola fruit juice powder. Journal of Pharmaceutical Sciences 41(5): 89-92.

Javadi, N., Abas, F., Hamid, A. A., Simoh, S., Shaari, K., Ismail, I. S., Mediani, A., dan Khatib, A. 2014. GCMS-based metabolite profiling of Cosmos caudatus leaves possessing alpha-glucosidase inhibitory activity. Journal of Food Science79(6): 1130-1136. DOI: 10.1111/1750-3841.12491

Jun, M., Fu, H. Y., Hong, J., Wan, X., Yang, C. S., dan Ho, C. T. 2003. Comparison of antioxidant activities of isoflavones from kudzu root (Pueraria lobata Ohwi). Journal of Food Science 68(6): 2117-2122. DOI: 10.1111/j.1365-2621.2003. tb07029.x 
Leon-Martinez, F. M., Mendez-Lagunas, L. L., dan Rodriguez-Ramirez, J. 2010. Spray drying of nopal mucilage (Opuntia ficus-indica): Effects on powder properties and characterization. Carbohydrate Polymers81(4): 864-870. DOI: 10.1016/j.carbpol.2010.03.061

Mediani, A., Abbas, F., Khatib, A., dan Tan, C. P. 2013. Cosmos caudatus as a potential source of polyphenolic compounds: optimisation of oven drying conditions and characterization of its functional properties. Molecules 18(9):1045210464. DOI: 10.3390/molecules 180910452

Mishra, P., Mishra, S., dan Mahanta, C. L. 2014. Effect of maltodextrin concentration and inlet temperature during spray drying on physicochemical and antioxidant properties of amla (Emblica officinalis) juice powder. Food and Bioproducts Processing 92(3): 252-258. DOI:10.1016/j.fbp.2013.08.003

Noriham, A., Dian-Nashiela, F., Hafifi, B. K., Nooraain, H., dan Azizah, A. H. 2015. Influences of maturity stages and extraction solvents on antioxidant activity of Cosmos caudatus leaves. Int. J. Res. Stud. Biosci. 3(12): 1-10.

Quek, S. Y., Chok, N. K., dan Swedlund, P. 2007. The physicochemical properties of spray dried watermelon powders. Chemical Engineering and Processing 46(5): 386-392. DOI: 10.1016/ j.cep.2006.06.020

Rahman, H. A., Saari, N., Abas, F., Ismail, A., Mumtaz, M. W., dan Hamid, A. A. 2016. Anti-obesity and antioxidant activities of selected medicinal plants and phytochemical profiling of bioactive compounds. International Journal of Food Properties 20(11): 2616-2629. DOI: 0.1080/ 10942912.2016 .1247098

Rahman, H. A., Sahib, N. G., Saari, N., Abas, F., Ismail, A., Mumtaz, M. W., dan Hamid, A. A. 2017. Antiobesity effect of ethanolic extract from Cosmos caudatus Kunth leaf in lean rats fed a high fat diet. BMC Complementary and Alternative Medicine 17(1): 1-17. DOI: 10.1186/s12906-017-1640-4.

Rufino, M. S. M, Alves, R. E., Brito, E. S., PerezJimenez, J., Saura-Calixto, F., Mancini-Filho, J. 2010. Bioactive compounds and antioxidant capacities of 18 non-traditional tropical fruits from Brazil. Food Chemistry 121(4): 996-1002. DOI: 10.1016/j.foodchem.2010.01.037

Saikia, S., Mahnot, N. K., dan Mahanta, C. L. 2015. Optimisation of phenolic extraction from Averrhoa carambola pomace by response surface methodology and its microencapsulation by spray and freeze drying. Food Chemistry 171(1): 144152. DOI: 10.1016/j.foodchem.2014.08.064

Samborska, K., Witrowa-Rajchert, D., dan Goncalves, A. 2005. Spray-drying of a-amylase: The effect of process variables on the enzyme inactivation. Drying Technology. 23(4): 941-953. DOI: 10.1081/DRT-200054243

Sobel, R., Versic, R., dan Gaonkar, A. G. 2014. Introduction to microencapsulation and controlled delivery in foods. Chpt. 1 in "Microencapsulation in the Food Industry," ed. A. Gaonkar, N. Vasisht, A. Khare, dan R. Sobel, pp. 1-12. Academic Press, California. 